\title{
Ceramide and ceramide 1-phosphate in health and disease
}

\author{
Lide Arana, Patricia Gangoiti, Alberto Ouro, Miguel Trueba and Antonio Gómez-Muñoz*
}

\begin{abstract}
Sphingolipids are essential components of cell membranes, and many of them regulate vital cell functions. In particular, ceramide plays crucial roles in cell signaling processes. Two major actions of ceramides are the promotion of cell cycle arrest and the induction of apoptosis. Phosphorylation of ceramide produces ceramide 1-phosphate (C1P), which has opposite effects to ceramide. C1P is mitogenic and has prosurvival properties. In addition, C1P is an important mediator of inflammatory responses, an action that takes place through stimulation of cytosolic phospholipase A2, and the subsequent release of arachidonic acid and prostaglandin formation. All of the former actions are thought to be mediated by intracellularly generated C1P. However, the recent observation that C1P stimulates macrophage chemotaxis implicates specific plasma membrane receptors that are coupled to Gi proteins. Hence, it can be concluded that C1P has dual actions in cells, as it can act as an intracellular second messenger to promote cell survival, or as an extracellular receptor agonist to stimulate cell migration.
\end{abstract}

\section{Introduction}

Sphingolipids play essential roles in normal cell and tissue homeostasis as well as in the establishment and progression of numerous diseases. In particular, ceramide is the central core in sphingolipid metabolism, but has also been involved in the regulation of signal transduction processes. Specifically, ceramides induce cell cycle arrest and promote apoptosis, a form of programmed cell death $[1,2]$. Also, ceramides play important roles in the regulation of autophagy, cell differentiation, survival, and inflammatory responses [3-11], and have been associated with insulin resistance through activation of protein phosphatase $2 \mathrm{~A}$ and the subsequent dephosphorylation and inactivation of Akt (also known as protein kinase B (PKB)) [12-14]. Cell ceramides typically have long $N$-acyl chains ranging from 16 to 26 carbons in length [15-17]. However, in many studies short-chain analogs ( $\mathrm{N}$-acetylsphingosine, or $\mathrm{C}_{2}$-ceramide, $\mathrm{N}$-hexanoylsphingosine, or C6-ceramide, and $\mathrm{N}$-octanoylsphingosine, or C8-ceramide) have been used in experiments because these are more water soluble than long-chain ceramides. Formation of ceramide is also relevant because it is the precur-

*Correspondence: antonio.gomez@ehu.es

1 Department of Biochemistry and Molecular Biology. Faculty of Science and Technology. University of the Basque Country (UPV/EHU). P.O. Box 644. 48080 Bilbao, Spain sor of important bioactive sphingolipids that can also regulate cellular functions, as discussed below.

A major metabolite of ceramide is ceramide-1-phosphate (C1P), which is generated through direct phosphorylation of ceramide by ceramide kinase (CerK) (Fig. 1). There is increasing evidence suggesting that $\mathrm{C} 1 \mathrm{P}$ can regulate cell proliferation and apoptosis [7,18], and Chalfant and co-workers have elegantly demonstrated that $\mathrm{C} 1 \mathrm{P}$ is a potent pro-inflammatory agent (Reviewed in $[19,20])$. In addition, C1P plays an important role in phagocytosis $[21,22]$, and we have recently demonstrated that is a key factor in the regulation of macrophage chemotaxis. The aim of the present review is to discuss recent progress in C1P biology with especial emphasis in the context of health and disease.

\section{Synthesis of Bioactive Sphingolipids}

Although sphingosine is the simplest sphingolipid, ceramide is considered to be the central structure in sphingolipid metabolism. Fig. 1 shows that ceramide can be generated by three major mechanisms: 1) the de novo synthesis pathway is an anabolic route that begins with condensation of the amino acid serine and palmitoylCoA to form 3-ketosphinganine in a reaction that is catalyzed by serine palmitoyltransferase (SPT); reduction of 3-ketosphinganine to sphinganine follows immediately; acylation of sphinganine by dihydroceramide synthase 


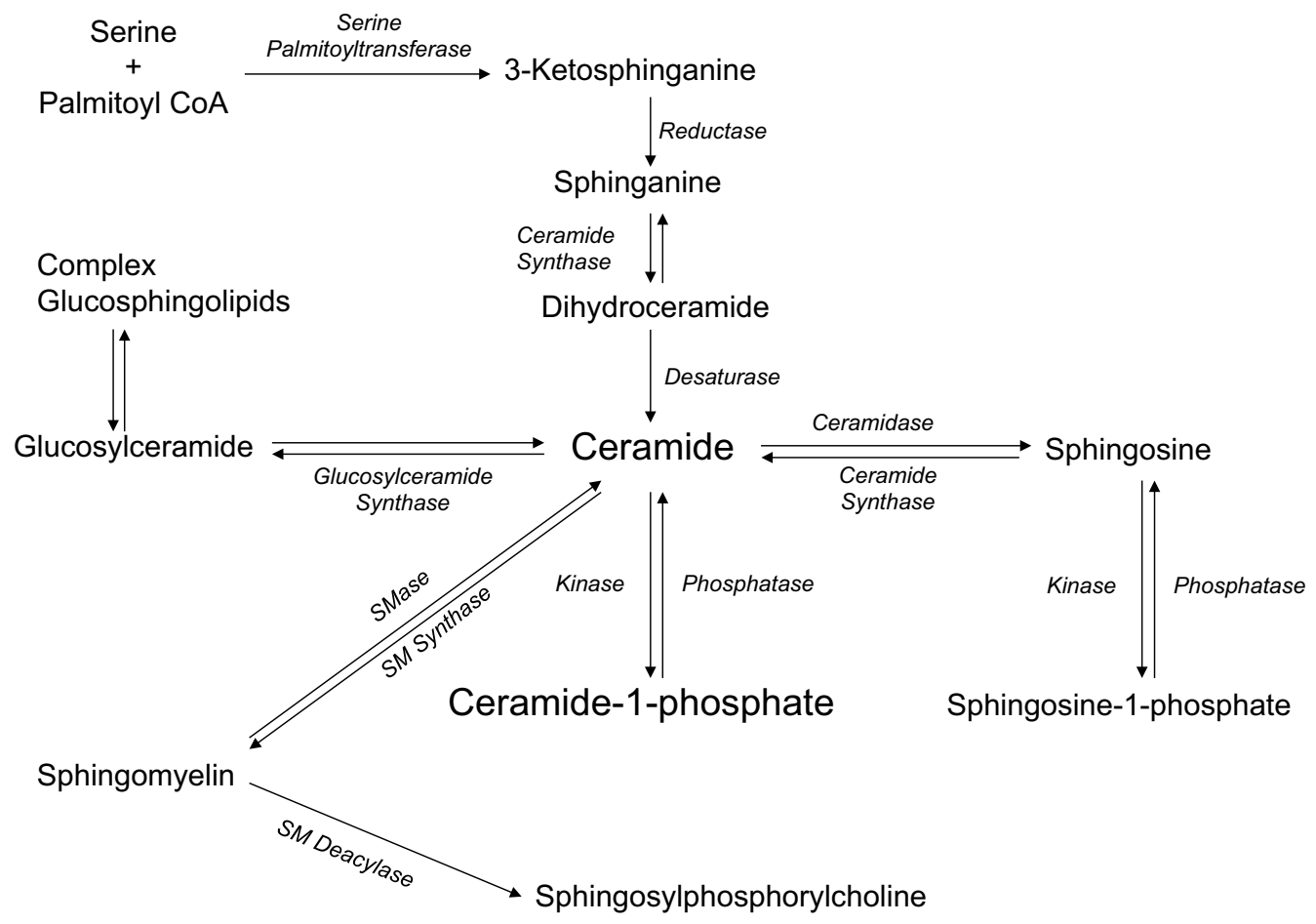

Figure 1 Formation of bioactive sphingolipids in mammalian cells. Ceramide can be produced by degradation of sphingomyelin (SM) by sphingomyelinases (SMase), or by de novo synthesis through the concerted action of serine palmitoyltransferase and dihydroceramide synthase. It can also be generated through metabolism of more complex sphingolipids. Ceramide can be metabolized to ceramide-1-phosphate by ceramide kinase, or to glucosylceramide by glucosylceramide synthase (GCS). The reverse reaction is catalyzed by ceramide-1-phosphate phosphatase, or by lipid phosphate phosphatases. Alternatively, ceramide can be degraded by ceramidases to form sphingosine, which can, in turn, be phosphorylated to sphingosine-1-phosphate by sphingosine kinase. The reverse reaction is catalyzed by sphingosine-1-phosphate phosphatases, or by lipid phosphate phosphatases. Sphingomyelin N-deacylase generates sphingosylphosphorylcholine.

(CerS, also known as Lass) then generates dihydroceramide. The last step of this pathway is catalyzed by a desaturase through introduction of a trans-4, 5 double bond in the dihydroceramide molecule to yield ceramide (Fig. 1). Concerning CerS six different genes have been identified in mammalian cells. Interestingly, the different CerS isoforms produce ceramide with different $\mathrm{N}$-acyl chains. The reason why there are so many of these genes when most of the other enzymes in the sphingolipid biosynthetic pathway exist in only one or two isoforms is not known. However, it is possible that ceramides containing different fatty acids play different roles in cell biology (reviewed in [23]). For details on SPT and CerS activities the reader is referred to other excellent reviews by Hannun and Obeid [2,5,24], and Merrill and co-workers $[11,25]$. Also, very elegant reviews by Kolesnick et al. [26], Goñi and Alonso [27], and Cremesti et al. [28] specifically address the important roles of SMase activities, enzymology, and compartmentalization in cell biology. Once synthesized, ceramide can be used for synthesis of complex sphingolipids, through intervention of different biosynthetic enzymes, including glucosyl or galactosyl ceramide synthases to form cerebrosides or gangliosides, or it can incorporate a phosphocholine head group from phosphatidylcholine (PC) to form SM through the action of SM synthases. Formation of glucosylceramide is particularly important because of its role in conferring drug resistance to tumor cells [29]. In addition, ceramide can be directly phosphorylated by ceramide kinase (CerK) to form C1P (Fig. 1), which is a key regulator of cell homeostasis $[18,30]$ and has been implicated in inflammatory responses $[19,20,31]$. 2) The second major mechanism for ceramide generation is a catabolic pathway involving activation of SMases to form phosphorylcholine and cer- 
amide directly (Fig. 1). There are three distinct forms of SMases in mammalian cells that can be discriminated in vitro by their optima $\mathrm{pH}$ : acid, neutral and alkaline SMases. Whilst acid SMase and neutral SMase are involved in signal transduction processes, the alkaline form of SMase is responsible for digestion of dietary SM in the intestine. The alkaline SMase isoform has now been re-named NPP7 because of its similarity to the nucleotide-pyrophosphatase/phosphodiesterase (NPP) family of enzymes. In addition to its role in SM digestion, a potential implication of this enzyme in cell signaling processes has also been suggested [32]. In particular alkaline SMase has been shown to inhibit cell proliferation in HT-29 colon carcinoma cells [33]. 3) The third important mechanism for generating ceramide is the sphingosine salvage pathway, in which sphingosine (produced from the metabolism of complex sphingolipids) is re-cycled to ceramide through the action of CerS. As mentioned above, another important enzyme that can control the levels of ceramide is sphingomyelin synthase (SMS) because it catalyzes the transfer of phosphorylcholine from phosphatidylcholine (PC) to ceramide, thereby releasing diacylglycerol (DAG) and lowering the levels of ceramide to produce SM. Interestingly, we have recently reported that SMS is implicated in the stimulation of PKC- $\alpha$ by C1P, an action that is linked to the mitogenic effect of this phosphosphingolipid in primary macrophages [34]. Ceramide can also be metabolized back to sphingosine by the action of specific ceramidases (Fig. 1). Sphingosine is also bioactive. It was first described as the physiological inhibitor of protein kinase C (PKC) [35]. There are many reports showing that $\mathrm{PKC}$ is inhibited by exogenous sphingosine, and Merrill and co-workers demonstrated that also endogenously generated sphingosine can inhibit protein kinase $C$ very potently [36]. In turn, sphingosine can control the activity of other key enzymes involved in the regulation of metabolic or cell signaling pathways such as the $\mathrm{Mg}^{2+}$ dependent form of phosphatidate phosphohydrolase [37,38], phospholipase D (PLD) [39], or diacylglycerol kinase (DAGK) [40,41] in a variety of cell types. In addition, sphingosine has been recently reported to be a ligand of the steroidogenic factor 1 (SF1) receptor, which is a nuclear receptor that plays a critical role in endocrine development of sex differentiation [42]. Endogenous sphingosine was found to be bound to this receptor under basal conditions, and treatment with cAMP decreased the amount of sphingosine bound to the receptor resulting in inhibition of cAMP-dependent CYP17 gene transcription [43]. Phosphorylation of sphingosine produces sphingosine 1-phosphate (S1P), which can regulate a variety of cellular functions including cell growth and survival, differentiation, and angiogenesis [19,44-46]. In addition, S1P stimulates cortisol and aldosterone secretion potently in cells of the zona fasciculata, and zona glomerulosa, respectively, suggesting that S1P is implicated in the regulation of steroidogenesis, and steroid hormone actions [47,48]. Two sphingosine kinases (SphKs) have so far been identified in mammalian cells, SphK1 and SphK2, which exhibit different biochemical properties and regulation. The roles of S1P and SphKs in cell biology have been extensively reviewed elsewhere $[42,49]$.

\section{Ceramides}

Besides its role as the precursor of complex sphingolipids ceramide is a signaling molecule capable of regulating vital cellular functions including apoptosis, cell growth, differentiation, senescence, diabetes, insulin resistance, inflammation, neurodegenerative disorders, or atherosclerosis[2-5,15,35,50-56]. In this connection, it should be pointed out that the topology of ceramide generation is crucial for determination of its functions as a bioregulatory molecule, with compartmentalization being essential for separation of signaling and metabolic pools within cells. Indeed, the enzymes that regulate ceramide metabolism show distinct subcellular localization and topology (reviewed in [2]). For instance, the plasma membrane of cells contains caveolae-associated neutral SMase, and a fraction of acid SMase, and the ceramides that are generated by these enzymes may have different functions. The enzymology, and compartmentalization of sphingomyelinases have been reviewed elsewhere [26-28]. Another important aspect of ceramide action concerns its transport from the ER, where it is synthesized, to the Golgi apparatus, the primary site of SM and glycosphingolipid synthesis. Hanada et al [57] recently demonstrated the existence of a specific protein that is involved in SM biosynthesis and acts as a ceramide transfer protein (CERT) in a non-vesicular manner. This protein has two domains involved in the transport of ceramide: one that recognizes ceramide and mediates its intermembrane transfer, termed the START domain, and a phosphatidylinositol binding domain (PH domain) with selectivity towards phosphatidylinositol-4-phosphate, a lipid that is enriched in the Golgi and that could serve as the site for ceramide delivery by CERT [57]. Ceramide generation at the plasma membrane exerts distinct and specific functions including aggregation of the Fas receptor, and effects on protein kinase $\mathrm{C}$ (PKC), but not other effects mediated by endogenous ceramides such as apoptosis, or cell cycle arrest [2]. Although the regulation of PKC activity by ceramides has already been reported, the results are still controversial. In this regard, ceramides have been shown to activate PKC- $\alpha$ and to inhibit PKC- $\alpha$ in renal mesangial cells [58]. They have also been shown to induce the translocation of PKC- $\alpha$ from the cytosol to the membrane [59], the translocation of PKC- $\delta$ and PKC- $\varepsilon$ from the membrane to the cytosol [60], and the translocation 
of PKC- $\delta$ from the cytosol to the mitochondria [61]. Also, ceramide was shown to induce apoptosis by translocation, tyrosine phosphorylation and activation of PKC- $\delta$ in the Golgi complex [62]. Another important target of ceramide is phospholipase D (PLD), which is a key regulatory enzyme responsible for generation of phosphatidic acid (PA), a potent mitogenic agent, and a precursor of important second messengers including lysoPA and diacylglycerol (DAG) [7]. We first reported that the cell-permeable ceramides $\mathrm{N}$-acetylsphingosine (C2-ceramide) and $\mathrm{N}$-hexanoylsphingosine (C6-ceramide), or exogenous bacterial sphingomyelinase, which can generate ceramides at the plasma membrane of cells, inhibited agonist-stimulated PLD activity potently in intact rat fibroblasts [63,64] or macrophages [65-67]. PLD inhibition by ceramides has also been demonstrated in several other cell types [47,68-70], as well as in cell-free systems $[71,72]$, or digitonin-permeabilized fibroblasts that were incubated with GTPYS [63]. However, the physiological significance of PLD inhibition by ceramides is still unclear.

Sphingolipids are also important because they are implicated in atherogenic processes (reviewed by Steinbrecher et al. [73]). In particular, ceramides, glycosphingolipids and S1P have been shown to accumulate in atherosclerotic lesions, and to participate in the regulation of signal transduction pathways that are implicated in atherogenesis. Ceramides and S1P can be generated by the action of oxidatively modified low density lipoproteins (LDL), or by pro-inflammatory cytokines. These bioactive sphingolipids can upregulate the expression of adhesion molecules and promote migration and adhesion of monocytes to the sites of lesions. In fact, early and intermediate atheromas are rich in macrophages and smooth muscle cells, and show evidence of active cell proliferation [74].

With regards to ceramide metabolism, the enzymes responsible for its degradation, have recently gained particular interest because of their involvement in various diseases. In particular ceramidases, would generate sphingosine directly, and sphingosine can be readily converted to S1P, a potent mitogenic agent and tumor promoter. Details on protein sequence, chromosomal location, tissue distribution, and subcellular localizations of the different ceramidases have been recently reviewed by Mao and Obeid [75]. Ceramidases have been implicated in the mitogenic effect of oxidized LDL (oxLDL), probably by enhancing the production of S1P [76]. Also, dysregulation of mesangial cell proliferation or death involves altered ceramidase activities [77-79] supporting a role of this enzyme in diabetic nephropathy. An involvement of the three different types of ceramidases (acid, neutral and alkaline) in the development of type 2 diabetes, insulin resistance and metabolic syndrome has also been reported [80-84]. Ceramidases appear to also be involved in some of the apoptotic effects promoted by nitric oxide [58,85-87] and inflammatory cytokines [8899], the antiapoptotic properties of growth factors $[100,101]$, and in the promotion of embryo survival by removing ceramides from newly formed embryos, thereby inhibiting the default apoptosis pathway [102]. Moreover, ceramidases attenuate peptidoglycan-induced COX-2 expression in macrophages [92], and the P. aeruginosa ceramidase enhances hemolysis induced phospholipase $C$ [103]. Increasing evidence points to important roles of ceramidases, specially the Asah1 isoform, in the outcome and progression of cancer, and the response of tumors to therapy (reviewed in $[33,95,104,105]$. Asah1 is overexpressed in several cancer cell lines and cancer tissues [106-111], which appears to contribute to decreasing the levels of ceramide and increasing those of S1P. Multiple reports confirm the relationship between Asah1 activity and radio or chemotherapy resistance, as well as the interest of Asah1 inhibitors as anticancer drugs. Also, in most cases, Asah1 inhibition induces apoptosis. In fact, high levels of Asah1 expression were found in a radiation resistant glioblastoma cell line when exposed to gammaradiation, and sensitivity to radiation was achieved by treatment with the ceramidase inhibitor $\mathrm{N}$-oleoylethanolamine (NOE), which significantly increased ceramide levels, caspase activation and apoptosis [60]. In search for ceramidase inhibitors, most efforts have been directed to Asah1 inhibition, because of their potential used as antiproliferative and cytostatic drugs for cancer chemotherapy. Ceramidase inhibitors have also been used in models other than cancer. For example, incubation of smooth muscle cells with oxLDL increased the activities of both acid and alkaline ceramidases and the mitogenic effect of oxLDL was inhibited by DMAPP, suggesting a role for ceramidases (probably through formation of S1P) in the mitogenic effect of oxLDL [76].

\section{Ceramide 1-phosphate}

Phosphorylation of ceramide seems to be the major mechanism for generation of C1P in cells. The only enzyme so far identified to induce the biosynthesis of C1P in mammalian cells is ceramide kinase (CerK). This enzyme was first observed in brain synaptic vesicles [112], and then found in human leukemia HL-60 monocytes [55]. CerK was found to be present in both the microsomal membrane fraction, and the cytosolic fraction of cells [113]. It was postulated that C1P traffics from the Golgi apparatus along the secretory pathway to the plasma membrane, and then released into the extracellular milieu to bind to acceptor proteins such as albumin or lipoproteins [114]. Recent work by Chalfant and co-workers [115] showed that CerK specifically utilizes ceramide transported to the trans-Golgi apparatus by ceramide 
transport protein (CERT). In fact, downregulation of CERT by RNA interference resulted in strong inhibition of newly synthesized C1P, suggesting that CERT plays a critical role in C1P formation. By contrast, Boath et al [114] recently reported that the transport of ceramides to the vicinity of CerK was not dependent on CERT. The reason for such discrepancy is unknown at present, but it might be possible that different cell types might have different subcellular distribution of CerK, and that expression of this enzyme might not be equal in all cell types. Concerning regulation of the enzyme activity, the dependency on $\mathrm{Ca}^{2+}$ ions is well established. CerK was also proposed to be regulated by phosphorylation/ dephosphorylation processes [116]. In addition, CerK location and activity seem to require the integrity of its PH domain, which includes a myristoylation site [116]. Another interesting aspect is that although CerK is the only enzyme so far described for generation of C1P in mammalian cells, bone marrow-derived macrophages (BMDM) from CerK-null mice (CerK-/-) still produced significant levels of C1P, suggesting the existence of a metabolic pathway, other than ceramide/CerK, for generation of C1P [114]. In particular, formation of C16-C1P, which is a major species of $\mathrm{C} 1 \mathrm{P}$ in cells, was not abolished in (CerK-/-) BMDM. We have previously speculated that two alternative pathways for generation of C1P in cells might be the transfer of a long acyl-CoA chain to S1P by a putative acyl transferase, or cleavage of SM by a PLD-like activity, similar to the existing arthropod or bacterial SMase D. However, work from our own lab [117] and that of others [114] have shown that acylation of S1P to form $\mathrm{C} 1 \mathrm{P}$ does not occur in mammalian cells. In addition, we found no evidence for intervention of SMase D activity when using rat fibroblasts. Nonetheless, these possibilities should be further explored in other cell types. Human CerK was cloned by Sugiura and co-workers [118]. The protein sequence has 537 amino acids with two protein sequence motifs, an $\mathrm{N}$-terminus that encompasses a sequence motif known as a pleckstrin homology $(\mathrm{PH})$ domain (amino acids 32-121), and a C-terminal region containing a $\mathrm{Ca}^{2+} /$ calmodulin binding domain (amino acids 124-433). It was found that leucine 10 in the $\mathrm{PH}$ domain is essential for its catalytic activity [119]. Also, it was shown that interaction between the $\mathrm{PH}$ domain of CerK and phosphatidylinositol 4,5-bisphosphate regulates the plasma membrane targeting and C1P levels [120]. More recently, the existence of a conserved cysteine motif in CerK that is also essential for its function was reported [121]. Also, it has been suggested that subcellular localization of CerK requires the interplay of their $\mathrm{PH}$ domain-containing $\mathrm{N}$-terminal regions together with the C-terminal domains [122]. Concerning substrate specificity, phosphorylation of ceramide by CerK is stereospecific [123]. It was reported that a minimum of a 12- carbon acyl chain is required for normal CerK activity, whereas the short-chain ceramide analogues $\mathrm{C}_{8}$-ceramide, $\mathrm{C}_{4}$-ceramide, or $\mathrm{C}_{2}$-ceramide were poor substrates for this enzyme. It was concluded that CerK phosphorylates only the naturally occurring D-erythro-ceramides [123]. However, Van Overloops and co-workers [124] observed that $\mathrm{C}_{2}$-ceramide is a good substrate for CerK, when albumin is used as a carrier, and that $\mathrm{C}_{2}$-ceramide can be converted to $\mathrm{C}_{2}$-C1P within cells. This raises the possibility that $\mathrm{C}_{2}-\mathrm{C} 1 \mathrm{P}$ is also a natural sphingolipid, capable of eliciting important biologic effects, as previously demonstrated (i.e. stimulation of cell proliferation [125]). The importance of CerK in cell signaling was highlighted using specific RNAi to inhibit this enzyme activity. This treatment blocked arachidonic acid (AA) release and $\mathrm{PGE}_{2}$ production in response to $\mathrm{ATP}$, the calcium ionophore A23187 and interleukin 1- $\beta[19,126]$. The relevance of this enzyme in cell biology was also highlighted in studies using CerK-/- mice; specifically, Bornancin and co-workers found a potent reduction in the amount of neutrophils in blood and spleen of these mice, whereas the amount of leukocytes, other than neutrophils, was increased in these animals. These observations pointed to an important role of CerK in neutrophil homeostasis [127]. Recently, a human ceramide kinaselike (CerKL) enzyme was identified in retina [128], and subsequently cloned [129]. However, this enzyme was unable to phosphorylate ceramide, or other related lipids, under conditions commonly used to measure CerK activity, and therefore its role in cell biology remains unclear. Importantly, intracellular formation of C1P was observed after challenging A549 lung adenocarcinoma cells with interleukin 1- $\beta$ [126], and after treatment of bone marrow-derived macrophages with M-CSF [130]. Also of importance, C1P levels were substantially decreased in apoptotic macrophages, suggesting that $\mathrm{C} 1 \mathrm{P}$ plays an important role in cell survival $[18,117]$.

\section{Role of ceramide 1-phosphate in cell growth and survival}

We recently reported that the mechanisms by which $\mathrm{C} 1 \mathrm{P}$ exerts its mitogenic effects involve stimulation of the mitogen-activated protein kinase kinase (MEK)/Extracellularly regulated kinases 1-2 (ERK1-2), phosphatidylinositol 3-kinase (PI3-K)/Akt (or PKB), and c-Jun terminal kinase (JNK) pathways [130]. We also found that C1P causes stimulation of the DNA binding activity of the transcription factor NF- $\mathrm{kB}$, and increases the expression of glycogen synthase kinase-3 $\beta$ (GSK-3 $\beta$ ) leading to upregulation of cyclin D1 and c-Myc, which are important markers of cell proliferation. Moreover, we have evidence suggesting that C1P-stimulated macrophage proliferation, implicates activation of SMS as well as translocation and activation of PKC- $\alpha$ [34], and that phospholipase D 
(PLD), intracellular calcium levels, or cAMP are not involved in this process [125,131].

In addition to its mitogenic effect, we also observed that $\mathrm{C} 1 \mathrm{P}$ is a potent inhibitor of apoptosis $[117,132]$. This finding was further supported by Mitra and co-workers [133] who found that down-regulation of CerK in mammalian cells reduced growth and promoted apoptosis in lung epithelial cells. However, Graf and co-workers reported that exogenous addition of the cell permeable $\mathrm{C}_{2}$-ceramide to cells overexpressing CerK led to $\mathrm{C}_{2}$-C1P formation and induction of apoptosis [134]. This contradictory observation can be explained by the fact that overexpression of CerK in the presence of abnormally high concentrations of ceramide (exogenously supplied) would cause and overwhelming increase in the intracellular levels of $\mathrm{C} 1 \mathrm{P}$, thereby reaching $\mathrm{C} 1 \mathrm{P}$ concentrations that are toxic for cells. In fact, we observed that in contrast to relatively low concentrations of $\mathrm{C} 1 \mathrm{P}$, which stimulate cell growth and inhibit apoptosis, relatively higher concentrations of $\mathrm{C} 1 \mathrm{P}$ are toxic and can kill the cells $[117,125]$. Concerning apoptosis, we also found that apoptotic bone marrow-derived macrophages have high acid SMase activity and high levels of ceramides compared to healthy cells $[135,136]$. Investigation into the mechanism whereby C1P exerts its anti-apoptotic effects led us to demonstrate that C1P caused potent inhibition of acid SMase and subsequent depletion of ceramide levels in intact macrophages [117]. C1P also blocked the activity of acid SMase in cell homogenates suggesting that inhibition of this enzyme occurs by direct physical interaction with C1P. It was concluded that C1P is a natural inhibitor of acid SMase, and that inhibition of this enzyme is a major mechanism whereby $\mathrm{C} 1 \mathrm{P}$ promotes cell survival [117]. Also, this observation suggests that inhibition of acid SMase by C1P is not mediated through receptor interaction. Acid SMase was also inhibited by S1P in intact macrophages [136], but the mechanism by which this action is brought about remains to be established. Recent work from our lab [137] shows that ceramide levels are also increased in apoptotic alveolar NR8383 macrophages. However, contrary to bone marrow-derived macrophages, there was little activation of neutral and acid SMases in the alveolar macrophages, suggesting that ceramides were generated through a different pathway in these cells. Investigation into the mechanisms whereby ceramide levels increased in alveolar macrophages revealed that activation of SPT, which as mentioned above is the key regulatory enzyme of the de novo pathway of ceramide synthesis, was a major factor in this process. Like for SMases, inhibition of SPT activation by treatment with C1P substantially decreased ceramide generation, and prevented the macrophages from entering apoptosis. It was concluded that $\mathrm{C} 1 \mathrm{P}$ promoted macrophage survival by blocking ceramide accumulation through inhibition of either SMase activity, or SPT, depending on cell type. The physiological relevance of the prosurvival effect of C1P was underscored by the demonstration that the intracellular levels of $\mathrm{C} 1 \mathrm{P}$ were substantially decreased in apoptotic macrophages. It can be hypothesized that the decrease in C1P concentration could result in the release of acid SMase, or SPT, from inhibition, thereby triggering ceramide generation an apoptotic cell death.

A well-established mechanism by which growth factors promote cell survival is through activation of phosphatidylinositol 3-kinase (PI3-K), which can lead to stimulation of the transcription factor NF- $\mathrm{KB}$, and expression of antiapoptotic genes. Using two different experimental approaches, we demonstrated that PI3-K was a target of C1P in bone marrow-derived macrophages [132]. PI3-K activation was demonstrated by immunoprecipitation of the enzyme from whole cell lysates and assayed in vitro using 32P-phosphatidylinositol. In addition, an in vivo approach provided evidence of phosphatidylinositol $(3,4,5)$-trisphosphate (PIP3) formation in intact cells that were prelabeled with ${ }^{32} \mathrm{P}$-orthophosphate [132]. Interestingly, PIP3, which is a major product of PI3-K activity, was shown to directly inhibit acid SMase [138]. Therefore, PI3-K activation may potentiate the inhibitory effect of C1P on acid SMase through generation of PIP3. We also observed that $\mathrm{C} 1 \mathrm{P}$ stimulated phosphorylation of $\mathrm{PKB}$, which is a target of kinases from different signaling pathways including PI3-K [139,140], cAMP or cAMPdependent protein kinase (PKA) [141,142], and PKC- $\zeta$ [143]. C1P-induced phosphorylation of PKB was sensitive to inhibition by wortmannin or LY294002, which are selective inhibitors of PI3K. These two inhibitors also blocked the prosurvival effect of $\mathrm{C} 1 \mathrm{P}$ indicating that $\mathrm{PKB}$ is downstream of PI3-K in macrophages, and important for the antiapoptotic effect of C1P [132]. C1P also caused IKB phosphorylation and stimulation of the DNA binding activity of NF- $\mathrm{kB}$ in primary cultures of mouse macrophages [132], and up-regulated the expression of antiapoptotic Bcl- $\mathrm{X}_{\mathrm{L}}$, which is a downstream target of NF- $\mathrm{kB}$. The latter results provided the first evidence for a novel biological role of natural $\mathrm{C} 1 \mathrm{P}$ in the regulation of cell survival by the PI3-K/PKB/NF-KB pathway in mammalian cells [132].

As mentioned above, C1P can be metabolized to ceramide by phosphatase activity, and then further converted to sphingosine and S1P by ceramidases and sphingosine kinases. Therefore, it could be speculated that the effects of $\mathrm{C} 1 \mathrm{P}$ might be mediated through C1Pderived metabolites. However, ceramides and C1P are antagonistic signals, and C1P is unable to mimic many of the effects of sphingosine or S1P (i.e. PLD activation, adenylyl cyclase inhibition, or $\mathrm{Ca}^{2+}$ mobilization) $[7,64,125,131]$. Also, ceramides can decrease the expres- 
sion of Bcl- $\mathrm{X}_{\mathrm{L}}$ [19], whereas C1P causes its up-regulation [132]. Finally, no ceramidases capable of converting C1P to S1P have so far been identified, and S1P and C1P inhibit acid SMase by different mechanisms $[117,136]$. Therefore, it can be concluded that C1P acts on its own right to regulate cell functions. The above observations suggest that the activity of the enzymes involved in ceramide and C1P metabolism must be strictly regulated. Any alteration in the balance between ceramides and C1P could potentially result in metabolic dysfunctions, and could be fatal for cells.

\section{Ceramide 1-phosphate and the control of inflammatory responses}

C1P has been demonstrated to be proinflammatory, which in principle is beneficial for protecting the organism against infection or injury. Inflammatory mediators include chemokynes, cytokines, vasoactive amines, products of proteolitic cascades, phospholipases, different forms of eicosanoids, and some sphingolipids. Generation of proinflammatory metabolites, however, should be blocked or at least reduced when inflammation becomes out of control, so as to protect the organism from major damage. Concerning phospholipases, a key mediator of inflammatory responses is cytosolic $\mathrm{PLA}_{2}\left(\mathrm{CPLA}_{2}\right)$, an enzyme that has been involved in receptor-dependent and independent release of arachidonic acid and eicosanoid production. With regards to sphingolipids, some of them have also been described as important mediators of inflammatory responses. For instance, ceramide was initially described as pro-inflammatory for different cell types [144-147], and more recently it has been implicated in the development of allergic asthmatic responses and airway inflammation [148]. In addition, exogenous addition of the short-chain cell permeable $\mathrm{C}_{2}$-ceramide, to cultured astrocytes upregulated the expression of 12lipoxygenase, thereby leading to generation of reactive oxygen species (ROS) and the initiation of inflammatory responses [149]. Acid sphingomyelinase-derived ceramide has also been involved in PAF-mediated pulmonary edema [150]. Subsequently, it was proposed that at least some of the pro-inflammatory effects of ceramides might in fact be mediated by its conversion to C1P. The first report on the regulation of arachidonic acid (AA) release and the production of prostaglandins by C1P was by Chalfant's group [126]. These authors demonstrated that $\mathrm{C} 1 \mathrm{P}$ potently and specifically stimulated AA release and prostanoid synthesis in A549 lung adenocarcinoma cells. In the same report, the authors showed that C1P could be generated intracellularly through stimulation of CerK by the action of interleukin 1- $\beta$. In a later report, the same group demonstrated that the mechanism whereby $\mathrm{C} 1 \mathrm{P}$ stimulates AA release occurs through direct activation of $\mathrm{cPLA}_{2}$ [151]. Subsequently, Subramanian and co-workers [152] found that $\mathrm{C} 1 \mathrm{P}$ is a positive allosteric activator of group IV $\mathrm{CPLA}_{2}$, and that it enhances the interaction of the enzyme with phosphatidylcholine. The authors concluded that C1P may function to recruit cPLA $2 \alpha$ to intracellular membranes and that it allosterically increases the catalytic ability of the membrane-associated enzyme [152]. In addition, recent studies demonstrated that activation of group IV $\mathrm{CPLA}_{2}$ by $\mathrm{C} 1 \mathrm{P}$ is chain length-specific. In particular, $\mathrm{C} 1 \mathrm{P}$ with acyl chains equal or higher than 6 carbons were able to efficiently activate $\mathrm{cPLA}_{2} \alpha$ in vitro, whereas shorter acyl chains (in particular $\mathrm{C}_{2}-\mathrm{C} 1 \mathrm{P}$ ) were unable to activate this enzyme. C1P was suggested to act in coordination with S1P to ensure maximal production of prostaglandins [153]. For details on the role of $\mathrm{C} 1 \mathrm{P}$ in inflammatory response the reader is referred to elegant reviews by Lamour and Chalfant [115]; Wijesinghe et al [154] and Chalfant and Spiegel [19]. It should also be pointed out that C1P is involved in other inflammatory processes including stimulation of phagocytosis in neutrophils $[21,22]$, activation of degranulation in mast cells [113], and more recently, stimulation of macrophage migration [155]. Nonetheless, apart from its clearly proinflammatory actions, C1P might act as antiinflammatory under specific conditions. In this context, it was postulated that activation of acid SMase plays an important role in pulmonary infections as it facilitates internalization of bacteria into lung epithelial cells [156]. Therefore, the recent finding that C1P potently inhibits acid SMase [116] could be important to reduce or prevent infection in the lung, an action that would obviously result in the inhibition of inflammatory responses.

\section{Ceramide 1-phosphate mediates macrophage migration}

Macrophages are involved in a number of chronic diseases that are characterized by unregulated chronic inflammation. These include autoimmune diseases, atherosclerosis, or multiple sclerosis [157], as well as tumor progression and metastasis [158]. Using Raw 264.7 macrophages, our group has recently demonstrated that exogenous addition of $\mathrm{C} 1 \mathrm{P}$ potently stimulated cell migration [155]. This action could only be observed when C1P was applied exogenously, but not when C1P was generated intracellularly. The intracellular levels of C1P were enhanced using different experimental approaches, including agonist stimulation of CerK, or delivery of $\mathrm{C} 1 \mathrm{P}$ using the photolabile caged-C1P compounds 7-(diethylamino)-coumarin (DECM), or 4-bromo-5-hydroxy-2nitrobenzhydryl (BHNB) [159] to the cells in culture but macrophages failed to migrate (A. Ouro et al., unpublished work). These observations led to identify a specific plasma membrane receptor that stimulates chemotaxis upon ligation with $\mathrm{C} 1 \mathrm{P}$. This receptor had low affinity for 
C1P, with a $K_{d}$ value of approximately $7.8 \mu \mathrm{M}$. In addition, studies using GTP $\gamma$ S, and pertussis toxin, which potently blocks Gi proteins, provided evidence that the $\mathrm{C} 1 \mathrm{P}$ receptor is coupled to a $G_{i}$ protein. Interestingly, ligation of the receptor with $\mathrm{C} 1 \mathrm{P}$ caused potent phosphorylation of ERK1-2 and PKB, suggesting that these kinases are downstream of receptor activation. Of importance, inhibition of these pathways with selective inhibitors of MEK, the enzyme that phosphorylate ERK, and selective inhibitors of PI3-K, completely abolished C1P-stimulated macrophage migration. Furthermore, $\mathrm{C} 1 \mathrm{P}$ stimulated the DNA binding activity of NF- $\mathrm{kB}$, which is downstream of PKB or ERK, and blockade of this transcription factor also resulted in complete inhibition of macrophage migration. These observations suggested that MEK/ ERK1-2, PI3-K/PKB (Akt) and NF- $\mathrm{kB}$ are crucial components of the cascade of events leading to stimulation of cell migration by $\mathrm{C1P}$. It is possible that this newly identified receptor as well as the enzymes responsible for C1P generation might be important targets for treatment of illnesses that are associated to inflammation and cell migration, such as atherosclerosis or cancer. In this connection, two inhibitors of CerK have been recently described. One of these inhibitors is an analog of a previously reported SphK inhibitor named F-12509A [160], which inhibits CerK at $\mu$ molar concentrations without affecting the activities of SphK or diacylglycerol kinases. A second compound named NVP-231 (adamantane-1carboxylic acid (2-benzoylamino-benzothiazol-6-yl) amide) [161], inhibited CerK potently in a competitive and reversible manner at low nanomolar concentrations. Interestingly, when NVP-231 was combined with tamoxifen, a drug that is commonly used for treatment of breast cancer [162,163], it synergistically increased ceramide levels and blocked cell growth [161]. Also of interest, recent work by Zor and co-workers has produced a C1P analogue named phosphoceramide analogue-1 (PCERA1 ), which has potent anti-inflammatory properties [164]. The activity of PCERA-1 seems to be mediated by a cell membrane receptor that is distinct to the $\mathrm{C} 1 \mathrm{P}$ receptor described here. PCERA-1, and perhaps other compounds that may be eventually derived from modification of its original structure, might turn to also be useful tools for developing alternative strategies for treatment of inflammatory diseases.

\section{Concluding Remarks}

Detailed knowledge of the mechanisms controlling ceramide and C1P levels, including expression of the enzymes involved in their metabolism, and the receptors implicated in their actions, may be essential for developing molecular strategies to counteract metabolic disorders. Specifically serine palmitoyltransferases, ceramide synthases, sphingomyelinases, ceramide kinase, cerami- dases, and the different sphingolipid receptors are likely to be major targets for controlling sphingolipid actions, and metabolism. Finding selective inhibitors of these enzymes, as well as agonists and antagonists of these receptors will enhance our knowledge and understanding on how these molecules can control physiological and pathological processes including cell growth, differentiation, migration, neurodegeneration, cell death, inflammation, and cancer.

\section{Abbreviations}

BMDM: bone marrow-derived macrophages; $\mathrm{C}_{2}$-ceramide: $\mathrm{N}$-acetylsphingosine; C8-ceramide: N-octanoylsphingosine; C1P: ceramide-1-phosphate; DAG: diacylglycerol; ERK: extracellular regulated kinase; MAPK: mitogen-activated protein kinase; M-CSF: monocyte-colony stimulating factor; OxLDL: oxidized low density lipoproteins; LPP: lipid phosphate phosphatase; PA: phosphatidate; PC: phosphatidylcholine; PE: phosphatidylethanolamine; PI: phosphatidylinositol; PI3-K: phosphatidylinositol 3-kinase; PIP3: phosphatidylinositol $(3,4,5)$ trisphosphate; PS: phosphatidylserine; PLA $A_{2}$ : phospholipase $A_{2}$; PKB: protein kinase B; PKC: protein kinase C; PLC: phospholipase C; PLD: phospholipase D; SM: sphingomyelin; S1P: sphingosine-1-phosphate; SphK: sphingosine kinase.

\section{Competing interests}

The authors declare that they have no competing interests.

\section{Authors' contributions}

All authors participated in the writing of the manuscript.

All authors read and approved the final manuscript.

\section{Acknowledgements}

Current work in AGM lab is supported by grants BFU2009-13314/BMC from "Ministerio de Ciencia e Innovación", S-PE09UN42 from "Departamento de Industria, Comercio y Turismo del Gobierno Vasco", and Fundación Ramón Areces (Spain). LA, PG, and AO are fellows of the Basque Government.

\section{Author Details}

Department of Biochemistry and Molecular Biology. Faculty of Science and Technology. University of the Basque Country (UPV/EHU). P.O. Box 644. 48080 Bilbao, Spain

Received: 28 December 2009 Accepted: 5 February 2010 Published: 5 February 2010

\section{References}

1. Zheng W, Kollmeyer J, Symolon H, Momin A, Munter E, Wang E, Kelly S, Allegood JC, Liu Y, Peng Q, et al:: Ceramides and other bioactive sphingolipid backbones in health and disease: lipidomic analysis, metabolism and roles in membrane structure, dynamics, signaling and autophagy. Biochim Biophys Acta 2006, 1758:1864-1884.

2. Hannun YA, Obeid LM: The Ceramide-centric universe of lipid-mediated cell regulation: stress encounters of the lipid kind. J Bio/ Chem 2002, 277:25847-25850.

3. Kolesnick R, Golde DW: The sphingomyelin pathway in tumor necrosis factor and interleukin-1 signaling. Cell 1994, 77:325-328.

4. Hannun YA: The sphingomyelin cycle and the second messenger function of ceramide. J Biol Chem 1994, 269:3125-3128.

5. Hannun YA, Obeid LM: Ceramide: an intracellular signal for apoptosis. Trends Biochem Sci 1995, 20:73-77.

6. Dressler KA, Mathias S, Kolesnick RN: Tumor necrosis factor-alpha activates the sphingomyelin signal transduction pathway in a cell-free system. Science 1992, 255:1715-1718.

7. Gomez-Munoz A: Modulation of cell signalling by ceramides. Biochim Biophys Acta 1998, 1391:92-109.

8. Mathias S, Dressler KA, Kolesnick RN: Characterization of a ceramideactivated protein kinase: stimulation by tumor necrosis factor alpha. Proc Natl Acad Sci USA 1991, 88:10009-10013. 
9. Mathias S, Kolesnick R: Ceramide: a novel second messenger. Adv Lipid Res 1993, 25:65-90.

10. Okazaki T, Bielawska A, Bell RM, Hannun YA: Role of ceramide as a lipid mediator of 1 alpha,25-dihydroxyvitamin D3-induced HL-60 cell differentiation. J Biol Chem 1990, 265:15823-15831.

11. Menaldino DS, Bushnev A, Sun A, Liotta DC, Symolon H, Desai K, Dillehay DL, Peng Q, Wang E, Allegood J, et al:: Sphingoid bases and de novo ceramide synthesis: enzymes involved, pharmacology and mechanisms of action. Pharmacol Res 2003, 47:373-381.

12. Adams JM, Pratipanawatr T, Berria R, Wang E, DeFronzo RA, Sullards MC, Mandarino LJ: Ceramide content is increased in skeletal muscle from obese insulin-resistant humans. Diabetes 2004, 53:25-31.

13. Schmitz-Peiffer $C$ : Protein kinase $C$ and lipid-induced insulin resistance in skeletal muscle. Ann NY Acad Sci 2002, 967:146-157.

14. Stratford S, Hoehn KL, Liu F, Summers SA: Regulation of insulin action by ceramide: dual mechanisms linking ceramide accumulation to the inhibition of Akt/protein kinase B. J Biol Chem 2004, 279:36608-36615.

15. Merrill AH Jr: De novo sphingolipid biosynthesis: a necessary, but dangerous, pathway. J Biol Chem 2002, 277:25843-25846.

16. Merrill AH Jr, Sullards MC, Allegood JC, Kelly S, Wang E: Sphingolipidomics: high-throughput, structure-specific, and quantitative analysis of sphingolipids by liquid chromatography tandem mass spectrometry. Methods 2005, 36:207-224.

17. Pettus BJ, Bielawska A, Kroesen BJ, Moeller PD, Szulc ZM, Hannun YA Busman M: Observation of different ceramide species from crude cellular extracts by normal-phase high-performance liquid chromatography coupled to atmospheric pressure chemical ionization mass spectrometry. Rapid Commun Mass Spectrom 2003, 17:1203-1211.

18. Gomez-Munoz A: Ceramide-1-phosphate: a novel regulator of cell activation. FEBS Lett 2004, 562:5-10.

19. Chalfant CE, Spiegel S: Sphingosine 1-phosphate and ceramide 1phosphate: expanding roles in cell signaling. J Cell Sci 2005, 118:4605-4612.

20. Lamour NF, Chalfant CE: Ceramide-1-phosphate: the "missing" link in eicosanoid biosynthesis and inflammation. Mol Interv 2005, 5:358-367.

21. Hinkovska-Galcheva V, Boxer LA, Kindzelskii A, Hiraoka M, Abe A, Goparju S, Spiegel S, Petty HR, Shayman JA: Ceramide 1-phosphate, a mediator of phagocytosis. J Biol Chem 2005, 280:26612-26621.

22. Hinkovska-Galcheva VT, Boxer LA, Mansfield PJ, Harsh D, Blackwood A, Shayman JA: The formation of ceramide-1-phosphate during neutrophil phagocytosis and its role in liposome fusion. J Biol Chem 1998, 273:33203-33209.

23. Pewzner-Jung Y, Ben-Dor S, Futerman AH: When do Lasses (longevity assurance genes) become CerS (ceramide synthases)?: Insights into the regulation of ceramide synthesis. J Biol Chem 2006, 281:25001-25005.

24. Hannun YA, Obeid LM: Principles of bioactive lipid signalling: lessons from sphingolipids. Nat Rev Mol Cell Biol 2008, 9:139-150.

25. Desai K, Sullards MC, Allegood J, Wang E, Schmelz EM, Hartl M, Humpf HU, Liotta DC, Peng Q, Merrill AH Jr: Fumonisins and fumonisin analogs as inhibitors of ceramide synthase and inducers of apoptosis. Biochim Biophys Acta 2002, 1585:188-192.

26. Kolesnick RN, Goni FM, Alonso A: Compartmentalization of ceramide signaling: physical foundations and biological effects. J Cell Physiol 2000, 184:285-300.

27. Goni FM, Alonso A: Sphingomyelinases: enzymology and membrane activity. FEBS Lett 2002, 531:38-46.

28. Cremesti AE, Goni FM, Kolesnick R: Role of sphingomyelinase and ceramide in modulating rafts: do biophysical properties determine biologic outcome? FEBS Lett 2002, 531:47-53.

29. Gouaze-Andersson V, Cabot MC: Glycosphingolipids and drug resistance. Biochim Biophys Acta 2006, 1758:2096-2103.

30. Gomez-Munoz A: Ceramide 1-phosphate/ceramide, a switch between life and death. Biochim Biophys Acta 2006, 1758:2049-2056.

31. Pettus BJ, Chalfant CE, Hannun YA: Sphingolipids in inflammation: roles and implications. Curr Mol Med 2004, 4:405-418.

32. Hertervig E, Nilsson A, Cheng Y, Duan RD: Purified intestinal alkaline sphingomyelinase inhibits proliferation without inducing apoptosis in HT-29 colon carcinoma cells. J Cancer Res Clin Oncol 2003, 129:577-582.

33. Duan RD, Nilsson A: Metabolism of sphingolipids in the gut and its relation to inflammation and cancer development. Prog Lipid Res 2009, 48:62-72.
34. Gangoiti P, Granado MH, Arana L, Ouro A, Gomez-Munoz A: Activation of protein kinase $C$-alpha is essential for stimulation of cell proliferation by ceramide 1-phosphate. FEBS Lett 2010, 584(3):517-24. Epub 2009 Nov 2735. Hannun YA, Loomis CR, Merrill AH Jr, Bell RM: Sphingosine inhibition of protein kinase $\mathrm{C}$ activity and of phorbol dibutyrate binding in vitro and in human platelets. J Biol Chem 1986, 261:12604-12609.

36. Smith ER, Jones PL, Boss JM, Merrill AH Jr: Changing J774A.1 cells to new medium perturbs multiple signaling pathways, including the modulation of protein kinase $\mathrm{C}$ by endogenous sphingoid bases. $\mathrm{J}$ Biol Chem 1997, 272:5640-5646.

37. Gomez-Munoz A, Hamza EH, Brindley DN: Effects of sphingosine, albumin and unsaturated fatty acids on the activation and translocation of phosphatidate phosphohydrolases in rat hepatocytes. Biochim Biophys Acta 1992, 1127:49-56.

38. Jamal Z, Martin A, Gomez-Munoz A, Brindley DN: Plasma membrane fractions from rat liver contain a phosphatidate phosphohydrolase distinct from that in the endoplasmic reticulum and cytosol. J Biol Chem 1991, 266:2988-2996.

39. Natarajan V, Jayaram HN, Scribner WM, Garcia JG: Activation of endothelial cell phospholipase $D$ by sphingosine and sphingosine-1phosphate. Am J Respir Cell Mol Biol 1994, 11:221-229.

40. Sakane F, Yamada K, Kanoh H: Different effects of sphingosine, R59022 and anionic amphiphiles on two diacylglycerol kinase isozymes purified from porcine thymus cytosol. FEBS Lett 1989, 255:409-413.

41. Yamada K, Sakane F, Imai S, Takemura H: Sphingosine activates cellular diacylglycerol kinase in intact Jurkat cells, a human T-cell line. Biochim Biophys Acta 1993, 1169:217-224.

42. Liu H, Sugiura M, Nava VE, Edsall LC, Kono K, Poulton S, Milstien S, Kohama T, Spiegel S: Molecular cloning and functional characterization of a novel mammalian sphingosine kinase type 2 isoform. J Biol Chem 2000, 275:19513-19520

43. Urs AN, Dammer E, Sewer MB: Sphingosine regulates the transcription of CYP17 by binding to steroidogenic factor-1. Endocrinology 2006, 147:5249-5258.

44. Spiegel S, English D, Milstien S: Sphingosine 1-phosphate signaling: providing cells with a sense of direction. Trends Cell Biol 2002, 12:236-242.

45. Spiegel S, Milstien S: Sphingosine-1-phosphate: an enigmatic signalling lipid. Nat Rev Mol Cell Biol 2003, 4:397-407.

46. Spiegel S, Milstien S: Sphingosine 1-phosphate, a key cell signaling molecule. J Biol Chem 2002, 277:25851-25854

47. Rabano M, Pena A, Brizuela L, Marino A, Macarulla JM, Trueba M, GomezMunoz A: Sphingosine-1-phosphate stimulates cortisol secretion. FEBS Lett 2003, 535:101-105.

48. Brizuela L, Rabano M, Pena A, Gangoiti P, Macarulla JM, Trueba M, GomezMunoz A: Sphingosine 1-phosphate: a novel stimulator of aldosterone secretion. J Lipid Res 2006, 47:1238-1249.

49. Taha TA, Hannun YA, Obeid LM: Sphingosine kinase: biochemical and cellular regulation and role in disease. J Biochem Mol Biol 2006, 39:113-131.

50. Merrill AH Jr: Cell regulation by sphingosine and more complex sphingolipids. J Bioenerg Biomembr 1991, 23:83-104.

51. Merrill AH Jr, Jones DD: An update of the enzymology and regulation of sphingomyelin metabolism. Biochim Biophys Acta 1990, 1044:1-12.

52. Merrill AH Jr, Schmelz EM, Dillehay DL, Spiegel S, Shayman JA, Schroeder $\mathrm{JJ}$, Riley RT, Voss KA, Wang E: Sphingolipids--the enigmatic lipid class: biochemistry, physiology, and pathophysiology. Toxicol Appl Pharmacol 1997, 142:208-225.

53. Kolesnick R: The therapeutic potential of modulating the ceramide/ sphingomyelin pathway. J Clin Invest 2002, 110:3-8.

54. Kolesnick RN: 1,2-Diacylglycerols but not phorbol esters stimulate sphingomyelin hydrolysis in GH3 pituitary cells. J Biol Chem 1987, 262:16759-16762.

55. Kolesnick RN, Hemer MR: Characterization of a ceramide kinase activity from human leukemia (HL-60) cells. Separation from diacylglycerol kinase activity. J Biol Chem 1990, 265:18803-18808.

56. Hannun YA: Functions of ceramide in coordinating cellular responses to stress. Science 1996, 274:1855-1859.

57. Hanada K, Kumagai K, Yasuda S, Miura Y, Kawano M, Fukasawa M, Nishijima M: Molecular machinery for non-vesicular trafficking of ceramide. Nature 2003, 426:803-809. 
58. Huwiler A, Fabbro D, Pfeilschifter J: Selective ceramide binding to protein kinase $\mathrm{C}$-alpha and -delta isoenzymes in renal mesangial cells. Biochemistry 1998, 37:14556-14562.

59. Ibitayo Al, Sladick J, Tuteja S, Louis-Jacques O, Yamada H, Groblewski G, Welsh M, Bitar KN: HSP27 in signal transduction and association with contractile proteins in smooth muscle cells. Am J Physio/ 1999, 277:G445-454.

60. Sawai H, Okazaki T, Takeda Y, Tashima M, Sawada H, Okuma M, Kishi S, Umehara H, Domae N: Ceramide-induced translocation of protein kinase C-delta and -epsilon to the cytosol. Implications in apoptosis. J Biol Chem 1997, 272:2452-2458.

61. Sumitomo M, Ohba M, Asakuma J, Asano T, Kuroki T, Asano T, Hayakawa M: Protein kinase Cdelta amplifies ceramide formation via mitochondrial signaling in prostate cancer cells. J Clin Invest 2002, 109:827-836.

62. Kajimoto T, Shirai Y, Sakai N, Yamamoto T, Matsuzaki H, Kikkawa U, Saito N

: Ceramide-induced apoptosis by translocation, phosphorylation, and activation of protein kinase Cdelta in the Golgi complex. J Biol Chem 2004, 279:12668-12676.

63. Gomez-Munoz A, Martin A, O'Brien L, Brindley DN: Cell-permeable ceramides inhibit the stimulation of DNA synthesis and phospholipase D activity by phosphatidate and lysophosphatidate in rat fibroblasts. J Biol Chem 1994, 269:8937-8943.

64. Gomez-Munoz A, Waggoner DW, O'Brien L, Brindley DN: Interaction of ceramides, sphingosine, and sphingosine 1-phosphate in regulating DNA synthesis and phospholipase D activity. J Biol Chem 1995, 270:26318-26325

65. Gomez-Munoz A, Martens JS, Steinbrecher UP: Stimulation of phospholipase D activity by oxidized LDL in mouse peritoneal macrophages. Arterioscler Thromb Vasc Biol 2000, 20:135-143.

66. Gomez-Munoz A, O'Brien L, Hundal R, Steinbrecher UP. Lysophosphatidylcholine stimulates phospholipase $D$ activity in mouse peritoneal macrophages. J Lipid Res 1999, 40:988-993.

67. Gomez-Munoz A, O'Brien L, Steinbrecher UP: The platelet-activating factor receptor antagonist L-659,989 inhibits phospholipase D activity. Biochim Biophys Acta 1999, 1438:247-252.

68. Rabano M, Pena A, Brizuela L, Macarulla JM, Gomez-Munoz A, Trueba M: Angiotensin II-stimulated cortisol secretion is mediated by phospholipase D. Mol Cell Endocrinol 2004, 222:9-20

69. Venable ME, Obeid LM: Phospholipase D in cellular senescence. Biochim Biophys Acta 1999, 1439:291-298.

70. Perez-Andres E, Fernandez-Rodriguez M, Gonzalez M, Zubiaga A, Vallejo A, Garcia I, Matute C, Pochet S, Dehaye JP, Trueba M, et al:: Activation of phospholipase D-2 by P2X(7) agonists in rat submandibular gland acini. J Lipid Res 2002, 43:1244-1255.

71. Abousalham A, Liossis C, O'Brien L, Brindley DN: Cell-permeable ceramides prevent the activation of phospholipase $D$ by ADPribosylation factor and RhoA. J Biol Chem 1997, 272:1069-1075.

72. Venable ME, Bielawska A, Obeid LM: Ceramide inhibits phospholipase D in a cell-free system. J Biol Chem 1996, 271:24800-24805.

73. Steinbrecher UP, Gomez-Munoz A, Duronio V: Acid sphingomyelinase in macrophage apoptosis. Curr Opin Lipidol 2004, 15:531-537.

74. Kockx MM, De Meyer GR, Buyssens N, Knaapen MW, Bult H, Herman AG: Cell composition, replication, and apoptosis in atherosclerotic plaques after 6 months of cholesterol withdrawal. Circ Res 1998, 83:378-387.

75. Mao C, Obeid LM: Ceramidases: regulators of cellular responses mediated by ceramide, sphingosine, and sphingosine-1-phosphate. Biochim Biophys Acta 2008, 1781:424-434.

76. Auge N, Nikolova-Karakashian M, Carpentier S, Parthasarathy S, NegreSalvayre A, Salvayre R, Merrill AH Jr, Levade T: Role of sphingosine 1phosphate in the mitogenesis induced by oxidized low density lipoprotein in smooth muscle cells via activation of sphingomyelinase, ceramidase, and sphingosine kinase. J Biol Chem 1999, 274:21533-21538.

77. Geoffroy K, Troncy L, Wiernsperger N, Lagarde M, El Bawab S: Glomerular proliferation during early stages of diabetic nephropathy is associated with local increase of sphingosine-1-phosphate levels. FEBS Lett 2005, 579:1249-1254

78. Geoffroy K, Wiernsperger N, Lagarde M, El Bawab S: Bimodal effect of advanced glycation end products on mesangial cell proliferation is mediated by neutral ceramidase regulation and endogenous sphingolipids. J Biol Chem 2004, 279:34343-34352.
79. Zager RA, Conrad DS, Burkhart K: Ceramide accumulation during oxidant renal tubular injury: mechanisms and potential consequences. J Am Soc Nephrol 1998, 9:1670-1680.

80. Partovian C, Ju R, Zhuang ZW, Martin KA, Simons M: Syndecan-4 regulates subcellular localization of mTOR Complex2 and Akt activation in a PKCalpha-dependent manner in endothelial cells. $\mathrm{Mo}$ Cell 2008, 32:140-149.

81. Straczkowski M, Kowalska I, Baranowski M, Nikolajuk A, Otziomek E, Zabielski P, Adamska A, Blachnio A, Gorski J, Gorska M: Increased skeletal muscle ceramide level in men at risk of developing type 2 diabetes. Diabetologia 2007, 50:2366-2373.

82. Samad F, Hester KD, Yang G, Hannun YA, Bielawski J: Altered adipose and plasma sphingolipid metabolism in obesity: a potential mechanism for cardiovascular and metabolic risk. Diabetes 2006, 55:2579-2587.

83. Blachnio-Zabielska A, Zabielski P, Baranowski M, Gorski J: Effects of Streptozotocin-induced Diabetes and Elevation of Plasma FFA on Ceramide Metabolism in Rat Skeletal Muscle. Horm Metab Res 2010, 42:1-7.

84. Chavez JA, Holland WL, Bar J, Sandhoff K, Summers SA: Acid ceramidase overexpression prevents the inhibitory effects of saturated fatty acids on insulin signaling. J Biol Chem 2005, 280:20148-20153.

85. Franzen R, Fabbro D, Aschrafi A, Pfeilschifter J, Huwiler A: Nitric oxide induces degradation of the neutral ceramidase in rat renal mesangial cells and is counterregulated by protein kinase C. J Biol Chem 2002, 277:46184-46190.

86. Franzen $R$, Pfeilschifter J, Huwiler A: Nitric oxide induces neutral ceramidase degradation by the ubiquitin/proteasome complex in renal mesangial cell cultures. FEBS Lett 2002, 532:441-444

87. Pahan K, Sheikh FG, Khan M, Namboodiri AM, Singh I: Sphingomyelinase and ceramide stimulate the expression of inducible nitric-oxide synthase in rat primary astrocytes. J Biol Chem 1998, 273:2591-2600.

88. Amadou A, Nawrocki A, Best-Belpomme M, Pavoine C, Pecker F: Arachidonic acid mediates dual effect of TNF-alpha on $\mathrm{Ca} 2+$ transients and contraction of adult rat cardiomyocytes. Am J Physio/ Cell Physio 2002, 282:C1339-1347

89. Hatano Y, Terashi H, Arakawa S, Katagiri K: Interleukin-4 suppresses the enhancement of ceramide synthesis and cutaneous permeability barrier functions induced by tumor necrosis factor-alpha and interferon-gamma in human epidermis. J Invest Dermatol 2005, 124:786-792.

90. Radin MJ, Holycross BJ, Dumitrescu C, Kelley R, Altschuld RA: Leptin modulates the negative inotropic effect of interleukin-1beta in cardiac myocytes. Mol Cell Biochem 2008, 315:179-184

91. Oral H, Dorn GW, Mann DL: Sphingosine mediates the immediate negative inotropic effects of tumor necrosis factor-alpha in the adult mammalian cardiac myocyte. J Biol Chem 1997, 272:4836-4842.

92. Lin Cl, Chen CN, Chen JH, Lee H: Lysophospholipids increase IL-8 and MCP-1 expressions in human umbilical cord vein endothelial cells through an IL-1-dependent mechanism. J Cell Biochem 2006, 99:1216-1232

93. Kaszkin M, Huwiler A, Scholz K, Bosch H van den, Pfeilschifter J: Negative regulation of interleukin-1 beta-activated neutral sphingomyelinase by protein kinase $C$ in rat mesangial cells. FEBS Lett 1998, 440:163-166.

94. Franzen R, Pautz A, Brautigam L, Geisslinger G, Pfeilschifter J, Huwiler A Interleukin-1beta induces chronic activation and de novo synthesis of neutral ceramidase in renal mesangial cells. J Biol Chem 2001, 276:35382-35389.

95. Zeidan YH, Jenkins RW, Korman JB, Liu X, Obeid LM, Norris JS, Hannun YA: Molecular targeting of acid ceramidase: implications to cancer therapy. Curr Drug Targets 2008, 9:653-661.

96. Osawa Y, Uchinami H, Bielawski J, Schwabe RF, Hannun YA, Brenner DA: Roles for C16-ceramide and sphingosine 1-phosphate in regulating hepatocyte apoptosis in response to tumor necrosis factor-alpha. J Biol Chem 2005, 280:27879-27887.

97. Strelow A, Bernardo K, Adam-Klages S, Linke T, Sandhoff K, Kronke M, Adam D: Overexpression of acid ceramidase protects from tumor necrosis factor-induced cell death. J Exp Med 2000, 192:601-612.

98. De Vito WJ, Xhaja K, Stone S: Prenatal alcohol exposure increases TNFalpha-induced cytotoxicity in primary astrocytes. Alcohol 2000, 21:63-71.

99. Nikolova-Karakashian M, Morgan ET, Alexander C, Liotta DC, Merrill AH Jr: Bimodal regulation of ceramidase by interleukin-1beta. Implications 
for the regulation of cytochrome p450 2C11. J Biol Chem 1997 , 272:18718-18724

100. Coroneos E, Martinez M, McKenna S, Kester M: Differential regulation of sphingomyelinase and ceramidase activities by growth factors and cytokines. Implications for cellular proliferation and differentiation. $J$ Biol Chem 1995, 270:23305-23309.

101. Payne SG, Brindley DN, Guilbert LJ: Epidermal growth factor inhibits ceramide-induced apoptosis and lowers ceramide levels in primary placental trophoblasts. J Cell Physiol 1999, 180:263-270.

102. Eliyahu E, Park JH, Shtraizent N, He X, Schuchman EH: Acid ceramidase is a novel factor required for early embryo survival. FASEB J 2007, 21:1403-1409.

103. Okino N, Ito M: Ceramidase enhances phospholipase C-induced hemolysis by Pseudomonas aeruginosa. J Biol Chem 2007, 282:6021-6030.

104. Liu X, Elojeimy S, Turner LS, Mahdy AE, Zeidan YH, Bielawska A, Bielawski J, Dong JY, El-Zawahry AM, Guo GW, et al.: Acid ceramidase inhibition: a novel target for cancer therapy. Front Biosci 2008, 13:2293-2298.

105. Park JH, Schuchman EH: Acid ceramidase and human disease. Biochim Biophys Acta 2006, 1758:2133-2138.

106. Elojeimy S, Liu X, McKillop JC, El-Zawahry AM, Holman DH, Cheng JY, Meacham WD, Mahdy AE, Saad AF, Turner LS, et al:: Role of acid ceramidase in resistance to FasL: therapeutic approaches based on acid ceramidase inhibitors and FasL gene therapy. Mol Ther 2007, 15:1259-1263.

107. Seelan RS, Qian C, Yokomizo A, Bostwick DG, Smith DI, Liu W: Human acid ceramidase is overexpressed but not mutated in prostate cancer. Genes Chromosomes Cancer 2000, 29:137-146.

108. Perry DK, Carton J, Shah AK, Meredith F, Uhlinger DJ, Hannun YA: Serine palmitoyltransferase regulates de novo ceramide generation during etoposide-induced apoptosis. J Biol Chem 2000, 275:9078-9084.

109. Ruckhaberle E, Rody A, Engels K, Gaetje R, von Minckwitz G, Schiffmann S, Grosch S, Geisslinger G, Holtrich U, Karn T, Kaufmann M: Microarray analysis of altered sphingolipid metabolism reveals prognostic significance of sphingosine kinase 1 in breast cancer. Breast Cancer Res Treat 2008, 112:41-52.

110. Ruckhaberle E, Holtrich U, Engels K, Hanker L, Gatje R, Metzler D, Karn T, Kaufmann M, Rody A: Acid ceramidase 1 expression correlates with a better prognosis in ER-positive breast cancer. Climacteric 2009:1-12.

111. Saad AF, Meacham WD, Bai A, Anelli V, Elojeimy S, Mahdy AE, Turner LS, Cheng J, Bielawska A, Bielawski J, et al:: The functional effects of acid ceramidase overexpression in prostate cancer progression and resistance to chemotherapy. Cancer Biol Ther 2007, 6:1455-1460.

112. Bajjalieh SM, Martin TF, Floor E: Synaptic vesicle ceramide kinase. A calcium-stimulated lipid kinase that co-purifies with brain synaptic vesicles. J Biol Chem 1989, 264:14354-14360.

113. Mitsutake S, Kim TJ, Inagaki Y, Kato M, Yamashita T, Igarashi Y: Ceramide kinase is a mediator of calcium-dependent degranulation in mast cells. J Biol Chem 2004, 279:17570-17577.

114. Boath A, Graf C, Lidome E, Ullrich T, Nussbaumer P, Bornancin F: Regulation and traffic of ceramide 1-phosphate produced by ceramide kinase: comparative analysis to glucosylceramide and sphingomyelin. J Biol Chem 2008, 283:8517-8526.

115. Lamour NF, Stahelin RV, Wijesinghe DS, Maceyka M, Wang E, Allegood JC, Merrill AH Jr, Cho W, Chalfant CE: Ceramide kinase uses ceramide provided by ceramide transport protein: localization to organelles of eicosanoid synthesis. J Lipid Res 2007, 48:1293-1304.

116. Baumruker T, Bornancin F, Billich A: The role of sphingosine and ceramide kinases in inflammatory responses. Immunol Lett 2005, 96:175-185.

117. Gomez-Munoz A, Kong JY, Salh B, Steinbrecher UP: Ceramide-1phosphate blocks apoptosis through inhibition of acid sphingomyelinase in macrophages. J Lipid Res 2004, 45:99-105.

118. Sugiura M, Kono K, Liu H, Shimizugawa T, Minekura H, Spiegel S, Kohama T

: Ceramide kinase, a novel lipid kinase. Molecular cloning and functional characterization. J Biol Chem 2002, 277:23294-23300.

119. Kim TJ, Mitsutake S, Kato M, Igarashi Y: The leucine 10 residue in the pleckstrin homology domain of ceramide kinase is crucial for its catalytic activity. FEBS Lett 2005, 579:4383-4388.

120. Kim TJ, Mitsutake S, Igarashi Y: The interaction between the pleckstrin homology domain of ceramide kinase and phosphatidylinositol 4,5bisphosphate regulates the plasma membrane targeting and ceramide 1-phosphate levels. Biochem Biophys Res Commun 2006, 342:611-617.

121. Lidome E, Graf C, Jaritz M, Schanzer A, Rovina P, Nikolay R, Bornancin F: A conserved cysteine motif essential for ceramide kinase function. Biochimie 2008, 90:1560-1565.

122. Rovina P, Schanzer A, Graf C, Mechtcheriakova D, Jaritz M, Bornancin F: Subcellular localization of ceramide kinase and ceramide kinase-like protein requires interplay of their Pleckstrin Homology domaincontaining $\mathrm{N}$-terminal regions together with C-terminal domains. Biochim Biophys Acta 2009, 1791:1023-1030.

123. Wijesinghe DS, Massiello A, Subramanian P, Szulc Z, Bielawska A, Chalfant CE: Substrate specificity of human ceramide kinase. J Lipid Res 2005, 46:2706-2716.

124. Van Overloop H, Denizot Y, Baes M, Van Veldhoven PP: On the presence of C2-ceramide in mammalian tissues: possible relationship to etherphospholipids and phosphorylation by ceramide kinase. Biol Chem 2007, 388:315-324.

125. Gomez-Munoz A, Duffy PA, Martin A, O'Brien L, Byun HS, Bittman R, Brindley DN: Short-chain ceramide-1-phosphates are novel stimulators of DNA synthesis and cell division: antagonism by cell-permeable ceramides. Mol Pharmacol 1995, 47:833-839.

126. Pettus BJ, Bielawska A, Spiegel S, Roddy P, Hannun YA, Chalfant CE: Ceramide kinase mediates cytokine- and calcium ionophore-induced arachidonic acid release. J Biol Chem 2003, 278:38206-38213.

127. Tuson M, Marfany G, Gonzalez-Duarte R: Mutation of CERKL, a novel human ceramide kinase gene, causes autosomal recessive retinitis pigmentosa (RP26). Am J Hum Genet 2004, 74:128-138.

128. Graf C, Zemann B, Rovina P, Urtz N, Schanzer A, Reuschel R, Mechtcheriakova D, Muller M, Fischer E, Reichel C, et al: Neutropenia with Impaired Immune Response to Streptococcus pneumoniae in Ceramide Kinase-Deficient Mice. J Immunol 2008, 180:3457-3466.

129. Bornancin F, Mechtcheriakova D, Stora S, Graf C, Wlachos A, Devay P, Urtz $\mathrm{N}$, Baumruker T, Billich A: Characterization of a ceramide kinase-like protein. Biochim Biophys Acta 2005, 1687:31-43.

130. Gangoiti P, Granado MH, Wang SW, Kong JY, Steinbrecher UP, GomezMunoz A: Ceramide 1-phosphate stimulates macrophage proliferation through activation of the PI3-kinase/PKB, JNK and ERK1/2 pathways. Cell Signal 2008, 20:726-736.

131. Gomez-Munoz A, Frago LM, Alvarez L, Varela-Nieto I: Stimulation of DNA synthesis by natural ceramide 1-phosphate. Biochem J 1997, 325(Pt 2):435-440.

132. Gomez-Munoz A, Kong JY, Parhar K, Wang SW, Gangoiti P, Gonzalez M, Eivemark S, Salh B, Duronio V, Steinbrecher UP: Ceramide-1-phosphate promotes cell survival through activation of the phosphatidylinositol 3-kinase/protein kinase B pathway. FEBS Lett 2005, 579:3744-3750.

133. Mitra P, Maceyka M, Payne SG, Lamour N, Milstien S, Chalfant CE, Spiegel S

:Ceramide kinase regulates growth and survival of A549 human lung adenocarcinoma cells. FEBS Lett 2007, 581:735-740.

134. Graf C, Rovina P, Tauzin L, Schanzer A, Bornancin F: Enhanced ceramideinduced apoptosis in ceramide kinase overexpressing cells. Biochem Biophys Res Commun 2007, 354:309-314.

135. Hundal RS, Gomez-Munoz A, Kong JY, Salh BS, Marotta A, Duronio V, Steinbrecher UP: Oxidized low density lipoprotein inhibits macrophage apoptosis by blocking ceramide generation, thereby maintaining protein kinase B activation and Bcl-XL levels. J Biol Chem 2003, 278:24399-24408.

136. Gomez-Munoz A, Kong J, Salh B, Steinbrecher UP: Sphingosine-1phosphate inhibits acid sphingomyelinase and blocks apoptosis in macrophages. FEBS Lett 2003, 539:56-60.

137. Granado MH, Gangoiti P, Ouro A, Arana L, Gomez-Munoz A: Ceramide 1phosphate inhibits serine palmitoyltransferase and blocks apoptosis in alveolar macrophages. Biochim Biophys Acta 2009, 1791:263-272.

138. Testai FD, Landek MA, Goswami R, Ahmed M, Dawson G: Acid sphingomyelinase and inhibition by phosphate ion: role of inhibition by phosphatidyl-myo-inositol 3,4,5-triphosphate in oligodendrocyte cell signaling. J Neurochem 2004, 89:636-644.

139. Scheid MP, Woodgett JR: Unravelling the activation mechanisms of protein kinase B/Akt. FEBS Lett 2003, 546:108-112.

140. Scheid MP, Huber M, Damen JE, Hughes M, Kang V, Neilsen P, Prestwich $G D$, Krystal G, Duronio V: Phosphatidylinositol $(3,4,5) P 3$ is essential but not sufficient for protein kinase $B(P K B)$ activation; phosphatidylinositol $(3,4) \mathrm{P} 2$ is required for PKB phosphorylation at 
Ser-473: studies using cells from SH2-containing inositol-5phosphatase knockout mice. J Biol Chem 2002, 277:9027-9035.

141. Sable CL, Filippa N, Hemmings B, Van Obberghen E: cAMP stimulates protein kinase B in a Wortmannin-insensitive manner. FEBS Lett 1997, 409:253-257.

142. Filippa N, Sable CL, Filloux C, Hemmings B, Van Obberghen E:Mechanism of protein kinase $B$ activation by cyclic AMP-dependent protein kinase. Mol Cell Biol 1999, 19:4989-5000.

143. Van Kolen K, Gilany K, Moens L, Esmans EL, Slegers H: P2Y12 receptor signalling towards PKB proceeds through IGF-I receptor cross-talk and requires activation of Src, Pyk2 and Rap1. Cell Signal 2006, 18:1169-1181

144. Serhan CN, Haeggstrom JZ, Leslie CC: Lipid mediator networks in cell signaling: update and impact of cytokines. Faseb J 1996, 10:1 147-1158.

145. Manna SK, Aggarwal BB: IL-13 suppresses TNF-induced activation of nuclear factor-kappa B, activation protein-1, and apoptosis. J Immunol 1998, 161:2863-2872.

146. Newton R, Hart L, Chung KF, Barnes PJ: Ceramide induction of COX-2 and PGE(2) in pulmonary A549 cells does not involve activation of NFkappaB. Biochem Biophys Res Commun 2000, 277:675-679.

147. Hayakawa M, Jayadev S, Tsujimoto M, Hannun YA, Ito F: Role of ceramide in stimulation of the transcription of cytosolic phospholipase A2 and cyclooxygenase 2. Biochem Biophys Res Commun 1996, 220:681-686.

148. Masini E, Giannini L, Nistri S, Cinci L, Mastroianni R, Xu W, Comhair SA, Li D, Cuzzocrea S, Matuschak GM, Salvemini D: Ceramide: a key signaling molecule in a Guinea pig model of allergic asthmatic response and airway inflammation. J Pharmacol Exp Ther 2008, 324:548-557.

149. Prasad W, Nithipatikom K, Harder DR: Ceramide elevates 12hydroxyeicosatetraenoic acid levels and upregulates 12-lipoxygenase in rat primary hippocampal cell cultures containing predominantly astrocytes. Neurochem Int 2008, 53:220-229.

150. Goggel R, Winoto-Morbach S, Vielhaber G, Imai Y, Lindner K, Brade L, Brade H, Ehlers S, Slutsky AS, Schutze S, et al:: PAF-mediated pulmonary edema: a new role for acid sphingomyelinase and ceramide. Nat Med 2004, 10:155-160

151. Pettus BJ, Bielawska A, Subramanian P, Wijesinghe DS, Maceyka M, Leslie CC, Evans JH, Freiberg J, Roddy P, Hannun YA, Chalfant CE: Ceramide 1phosphate is a direct activator of cytosolic phospholipase A2. J Biol Chem 2004, 279:11320-11326.

152. Subramanian P, Stahelin RV, Szulc Z, Bielawska A, Cho W, Chalfant CE: Ceramide 1-phosphate acts as a positive allosteric activator of group IVA cytosolic phospholipase A2 alpha and enhances the interaction of the enzyme with phosphatidylcholine. J Bio/ Chem 2005, 280:17601-17607.

153. Pettus BJ, Kitatani K, Chalfant CE, Taha TA, Kawamori T, Bielawski J, Obeid LM, Hannun YA: The coordination of prostaglandin E2 production by sphingosine-1-phosphate and ceramide-1-phosphate. Mol Pharmacol 2005, 68:330-335.

154. Wijesinghe DS, Lamour NF, Gomez-Munoz A, Chalfant CE: Ceramide kinase and ceramide-1-phosphate. Methods Enzymol 2007, 434:265-292

155. Granado MH, Gangoiti P, Ouro A, Arana L, Gonzalez M, Trueba M, GomezMunoz A: Ceramide 1-phosphate (C1P) promotes cell migration Involvement of a specific C1P receptor. Cell Signal 2009, 21:405-412.

156. Gulbins E, Kolesnick R: Raft ceramide in molecular medicine. Oncogene 2003, 22:7070-7077

157. Hendriks JJ, Teunissen CE, de Vries HE, Dijkstra CD: Macrophages and neurodegeneration. Brain Res Brain Res Rev 2005, 48:185-195.

158. Condeelis J, Pollard JW: Macrophages: obligate partners for tumor cell migration, invasion, and metastasis. Cell 2006, 124:263-266.

159. Lankalapalli RS, Ouro A, Arana L, Gomez-Munoz A, Bittman R: Caged ceramide 1-phosphate analogues: synthesis and properties. J Org Chem 2009, 74:8844-8847.

160. Kim JW, Inagaki Y, Mitsutake S, Maezawa N, Katsumura S, Ryu YW, Park CS, Taniguchi M, Igarashi Y: Suppression of mast cell degranulation by a novel ceramide kinase inhibitor, the F-12509A olefin isomer K1. Biochim Biophys Acta 2005, 1738:82-90.

161. Graf C, Klumpp M, Habig M, Rovina P, Billich A, Baumruker T, Oberhauser $\mathrm{B}$, Bornancin F: Targeting ceramide metabolism with a potent and specific ceramide kinase inhibitor. Mol Pharmacol 2008, 74:925-932.

162. Lavie Y, Cao H, Volner A, Lucci A, Han TY Geffen V, Giuliano AE, Cabot MC. Agents that reverse multidrug resistance, tamoxifen, verapamil, and cyclosporin A, block glycosphingolipid metabolism by inhibiting ceramide glycosylation in human cancer cells. J Biol Chem 1997, 272:1682-1687.

163. Cabot MC, Giuliano AE, Volner A, Han TY: Tamoxifen retards glycosphingolipid metabolism in human cancer cells. FEBS Lett 1996, 394:129-131.

164. Goldsmith M, Avni D, Levy-Rimler G, Mashiach R, Ernst O, Levi M, Webb B, Meijler MM, Gray NS, Rosen H, Zor T: A ceramide-1-phosphate analogue, PCERA-1, simultaneously suppresses tumour necrosis factor-alpha and induces interleukin-10 production in activated macrophages. Immunology 2008

doi: 10.1186/1476-511X-9-15

Cite this article as: Arana et al., Ceramide and ceramide 1-phosphate in health and disease Lipids in Health and Disease 2010, 9:15

\section{Submit your next manuscript to BioMed Central} and take full advantage of:

- Convenient online submission

- Thorough peer review

- No space constraints or color figure charges

- Immediate publication on acceptance

- Inclusion in PubMed, CAS, Scopus and Google Scholar

- Research which is freely available for redistribution 